Jurnal Widya Sastra Pendidikan Agama Hindu, Vol 4, No. 1, 2021

ISSN: 2656-7466

\title{
PENERAPAN KONSEP TRI KAYA PARISUDHA PELATIHAN YOGA DALAM PEMBELAJARAN PENDIDIKAN AGAMA HINDU DAN BUDI PEKERTI
}

\author{
Oleh \\ I Nengah Dwi Endra Suanthara \\ dwisuanthara@gmail.com
}

\begin{abstract}
ABSTRAK
Model pembelajaran merupakan cara atau strategi yang digunakan guru dalam menelola pembelajaran untuk mencapai tujuan yang diinginkan. Capaian pembelajaran merupakan indikator keberhasilan yang dilakukan guru dalam proses belajar-mengajar. Fenomena rendahnya hasil belajar banyak dipengaruhi oleh kesalahan guru dalam memilih atau menggunakan metode atau model pembelajaran. Model atau metode yang konvensional tentu tidak berpengaruh untuk meningkatkan hasil belajar siswa. Tetapi model atau metode pembelajaran yang inovatif diduga sangat berpengaruh pada peningkatan hasil belajar siswa. Menemukan metode atau model pembelajaran baru merupakan tugas yang penting dilakukan oleh guru. Penelitian ini adalah penelitian eksperimen yang bertujuan untuk menemukan model pembelajaran baru yang bersumber dari ajaran Agama Hindu. Judul penelitiannya yaitu Perpaduan Konsep Tri Kaya Parisudha dengan Pelatihan Yoga Terhadap Prestasi Belajar Pendidikan Agama Hindu dan Budhi Pekerti. Penelitian ini dirancang dengan penelitian eksperimen model pre test post test control group disign. Populasi seluruh siswa kelas XI SMKN 3 Singaraja dengan jumlah sampel sebanyak 61 orang dengan rincian kelas eksperimen 31 orang dan kontrol 30 orang. Teknik sampling yang digunakan adalah claster random sampling dengan teknik undian. Metode pengumpulan data digunakan tes prestasi belajar, observasi digunakan untuk data aktivitas siswa dan wawan cara sebagai pelengkap. Analisis data digunakan analisis statistik inferensial melalui uji-t dan taraf signifikansi $5 \%$ di dapat th $(2,095)>t_{t}(1,671)$. Hasil penelitian bahwa ada pengaruh Perpaduan Konsep Tri Kaya Parisudha dengan Pelatihan Yoga Terhadap Prestasi Belajar Pendidikan Agama Hindu dan Budhi Pekerti. Hasil penelitian merekomendasikan bahwa para guru agama dan budhi pekerti membuat penelitian eksperimen khusus dibidang metode pembelajaran dengan mengambil aspek dari ajaran Agama Hidu serta mampu menggunakannya dengan tepat dan benar.
\end{abstract}

Kata Kunci: Konsep Tri Kaya Parisudha, Pelatihan Yoga, Prestasi Belajar

APPLICATION OF THE TRI KAYA PARISUDHA CONCEPT YOGA TRAINING IN LEARNING HINDU RELIGION AND BUDHI PEKERTI EDUCATION

I Nengah Dwi Endra Suanthara

dwisuanthara@gmail.com

ABSTRACT 
Keywords: Tri Kaya Parisudha Concept, Yoga Training, Learning Achievement The learning model was a method or strategy used by teachers in managing learning to achieve the desired goals. Learning achievement was an indicator of the success of the teacher in the teaching and learning process. The phenomenon of low learning outcomes was much influenced by teacher errors in choosing or using learning methods or models. Conventional models or methods certainly have no effect on improving student learning outcomes. However, innovative learning models or methods were thought to be very influential in improving student learning outcomes. Finding new learning methods or models was an important task for teachers. This research was an experimental research that aims to find a new learning model that comes from the teachings of Hinduism. The title of the research was the Combination of the Tri Kaya Parisudha Concept with Yoga Training on Learning Achievement in Hindu Religion and Budhi Pekerti Education. This study was designed with experimental research model pre test post test control group design. The population of all students of class XI SMKN 3 Singaraja with a total sample of 61 students with details of the experimental class 31 students and control 30 students. The sampling technique used was cluster random sampling with a lottery technique. Data collection methods used learning achievement tests, observations used for student activity data and interviews as a complement. Data analysis used inferential statistical analysis through t-test and a significance level of $5 \%$ in th $(2.095)>\mathrm{tt}$ (1.671). The results of the study showed that there was an effect of the combination of the Tri Kaya Parisudha concept with Yoga Training on the Learning Achievement education of Hindu Religious and Budhi Pekerti. The results of the study recommend that religious and ethical teachers make special experimental research in the field of learning methods by taking aspects of Hindu religion and Budhi Pekerti teachings and being able to use them appropriately and correctly.

\section{PENDAHULUAN}

Metode pembelajaran sangat penting untuk mengantarkan materi ajar agar dapat diterima oleh siswa. Oleh karena itu guru harus mampu memilih dan menggunakan metode pembelajaran yang tepat dan benar. Metode yang baik adalah memiliki prinsip efektivitas dan efesiensi serta produktivitas (Prihma Sinta Utami, 2018). IImu Agama Hindu adalah ilmu yang universal dalam isi atau materi maupun makna yang terkandung di dalamnya yang menyangkut Tattwa, Etik dan upacara. Keuniversalan Agama Hindu tentu sangat banyak mengandung ranah kognetif, afektif dan psikomotor. Dari bidang aspek tersebut dapat dikembangkan menjadi metode pembelajaran baru (Suanthara, 2020). Misalnya tri Kaya Parisudha, memuat tiga aspek utama yaitu: berpikir (manahcika), berkata (wacika) dan berbuat (kayika). Demikian juga halnya dengan yoga, yang merupakan bagian dari aspek Agama Hindu yang berarti olahraga jasmani dan mental yang fokus pada peningkatan kekuatan fisik, kelenturan, pernafasan serta seni dan budaya. Jika metode pembelajaran mampu mengkombinasikan kekuatan atau aktivitas pikiran, perkataan, perbuatan serta seni dan budaya maka materi yang disampaikan kepada siswa akan menjadi sangat indah, menarik dan tidak membosankan (Nabila Yuliana, 2018). Agama memiliki peran yang amat penting dalam kehidupan umat manusia. Agama menjadi pemandu dalam upaya untuk mewujudkan suatu kehidupan yang bermakna, damai dan bermartabat. Menyadari peran agama amat penting bagi kehidupan umat manusia maka internalisasi agama dalam kehidupan setiap pribadi menjadi sebuah keniscayaan, yang ditempuh melalui pendidikan baik pendidikan di lingkungan keluarga, di lembaga pendidikan formal maupun non formal. Pendidikan 
Agama dimaksudkan untuk membentuk peserta didik menjadi manusia yang beriman dan bertakwa kepada Tuhan Yang Maha Esa dan berakhlak mulia serta peningkatan potensi spritual. Akhlak mulia mencakup etika, budi pekerti, dan moral sebagai perwujudan dari pendidikan Agama. Peningkatan potensi spiritual mencakup pengenalan, pemahaman, dan penanaman nilai-nilai keagamaan, serta pengamalan nilai-nilai tersebut dalam kehidupan individual atau pun kolektif kemasyarakatan. Peningkatan potensi spiritual tersebut pada akhirnya bertujuan pada optimalisasi berbagai potensi yang dimiliki manusia yang aktualisasinya mencerminkan harkat dan martabatnya sebagai makhluk Tuhan (Suradarma, 2019). Keterampilan psikomotor ada enam tahap, yaitu: gerakan refleks, gerakan dasar, kemampuan perseptual, gerakan fisik, gerakan terampil, dan komunikasi non diskursif. Gerakan reflex adalah respons motorik atau gerak tanpa sadar yang muncul ketika bayi lahir. Gerakan dasar adalah gerakan yang mengarah pada keterampilan komplek yang khusus. Kemampuan perceptual adalah kombinasi kemampuan kognitif dan motorik atau gerak. Kemampuan fisik adalah kemampuan untuk mengembangkan gerakan terampil. Gerakan terampil adalah gerakan yang memerlukan belajar, seperti keterampilan dalam olah raga (Rusli, 2017). Komunikasi non diskursif adalah kemampuan berkomunikasi dengan menggunakan gerakan. Untuk jenjang Pendidikan SMA/SMK, mata pelajaran yang banyak berhubungan dengan ranah psikomotor adalah pendidikan jasmani, olahraga dan kesehatan, seni budaya, fisika, kimia, biologi, dan keterampilan. Dengan kata lain, kegiatan belajar yang banyak berhubungan dengan ranah psikomotor adalah praktik di aula atau lapangan dan praktikum di laboratorium. Bilamana pembelajaran mampu dilaksanakan dengan motode yang atraktif, seni dan dinamis maka tentu hasil atau capaian pembelajaran akan menjadi baik.

Namun fenomena yang Nampak dari hasil pre tes terhadap para siswa SMKN 3 Singaraja diperoleh hasil yang masihbelum memuaskan karena capaian pembelajaran siswa masih sebagian besar berada dibawah criteria ketuntasan minimal yang ditetapkan oleh Sekolah yaitu 80 untuk bidang studi pendidikan agama dan budhi pekerti. Hasil ini tentu tidak baik dalam proses pembelajaran karena akan dapat berkontribusi negatif terhadap kualitas pembelajaran, sikap atau karakter siswa. Kesalahan dalam memilih metode pembelajaran merupakan faktor yang penting harus dipertimbangkan. Banyak guru menggunakan metode pembelajaran yang sudah tidak update atau konvensional, karena mereka tidak ada kemauan atau kemampuan untuk menggali atau menemukan metode pembelajaran baru. Berdasarkan dari permasalahan tersebut peneliti melakukan penelitian eksperimen yang bertujuan untuk menemukan metode pembelajaran baru yang bersuber dari konsep ajaran Agama Hindu yaitu konsep ajaran Tri Kaya Parisudha dan Yoga.

\section{METODE PENELITIAN}

Penelitian ini dirancang dengan penelitian kuantitatif jenis eksperimen yang dilaksanakan di SMKN 3 Singaraja dan dilakukan secara random terhadap kelas yang ada. Rancangan penelitian yang digunakan adalah posttest only control group design. Dalam design ini terdapat dua kelompok yang masing-masing dipilih secara random. Kelompok pertama (eksperimen) diberi perlakuan sedangkan kelompokke dua disebut kelompok control tidak mendapat perlakuan (SUGIYONO, 2003). Menentukan kelas eksperimen dan control dilaksanakan dengan mengambil dua kelas secara random kemudian diambil satu dengan teknik undian sebagai kelas eksperimen. Jumlah populasi sebanyal 729 Siswa kelas XI sedangkan teknik sampling yang digunakan adalah classter random sampling dan teknik undian. 
Jumlah sampel sebanyak sebanyak 31 orang kelas eksperimen dan 30 orang untuk kelas control. Metode pengulan data digunakan tes prestasi belajar.tes yang digunakan telah memenuhi validitas dan reliabilitas. Sebelum data dianalisis dilakukan uji kesetaraan kelompok. Metode analisis digunakan statistik deskriptif dan inferensial. statistik deskriptif di gunakan untuk mendeskripsikan atau memaparkan data penelitian melalui angka rata-rata dan standar deviasi. Dalam penelitian ini menggunakan SPSS 16.0 for Windows. Sedangkan statistik inferensial digunakan untuk uji hipotesis penelitian dengan menggunakan rumus sebagai berikut.

\section{Uji Homoginitas Data}

$$
F=\frac{\text { V.Terbesar }}{\text { V.Terkecil }}
$$

\section{Uji Hipotesisnya}

$$
t=\frac{\bar{X}_{1}-\bar{X}_{2}}{\sqrt{\frac{\left(n_{1}-1\right) s_{1}^{2}+\left(n_{2}-1\right) s_{2}^{2}}{n_{1}+n_{2}-2}\left(\frac{1}{n_{1}}+\frac{1}{n_{2}}\right)}}
$$

Keterangan :

$$
\begin{aligned}
& \bar{X}_{1}{ }^{2}=\text { Rata-rata kelas eksperimen } \\
& \bar{X}_{2}{ }^{2}=\text { Rata-rata kelas kontrol } \\
& S_{1}{ }^{2}=\text { Simpangan baku atau standar deviasi kelas eksperimen } \\
& S_{2}{ }^{2}=\text { Simpangan baku atau standar deviasi kelas kontrol } \\
& n_{1}=\text { Jumlah sampel kelas eksperimen } \\
& n_{2}=\text { Jumlah sampel kelas kontrol }
\end{aligned}
$$

\section{HASIL DAN PEMBAHASAN}

Penelitian ini dilaksanakan di SMK Negeri 3 Singaraja dengan jumlah anggota sampel sebanyak 61 orang. Data yang terkumpul dianalisis dengan analisis statistik deskriptif dan analisis inferensial. Statistik deskriptif digunakan untuk mendeskripsi data dari variabel-variabel yang diteliti, sedangkan statistik inferensial digunakan untuk uji persyaratan analisis dan uji hipotesis. Sebuah penelitian ingin mengkaji perbedaan prestasi belajar Agama Hindu antara dua kelompok siswa, yaitu siswa yang belajar dengan model perpaduan konsep tri kaya parisudha dengan pelatihan yoga dan siswa yang belajar dengan model pembelajaran konvensional. Hipotesis yang diuji adalah sebagai berikut.

H0: Tidak terdapat perbedaan prestasi belajar antara siswa yang belajar dengan model perpaduan konsep tri kaya parisudha dengan pelatihan yoga dan siswa yang belajar dengan model pembelajaran konvensional 
$\mathrm{H}_{\mathrm{A}}$ : Terdapat perbedaan prestasi belajar antara siswa yang belajar dengan model perpaduan konsep tri kaya parisudha dengan pelatihan yoga dengan siswa yang belajar dengan model pembelajaran konvensional

Prestasi belajar kelas eksperimen (kelas XI MM-1) ini diperoleh menggunakan tes pilihan ganda dengan jumlah lima belas soal obyektif, masing-masing soal terdapat lima pilihan atau option ( $a, b, c, d$ dan e). Skor mentah minimum dan maksimum siswa adalah 0 dan 15 . Setiap butir soal memiliki poin 1, apabila tiap 1 butir soal dijawab dengan benar maka siswa mendapatkan point 1 dan sebaliknya jika siswa tidak bisa menjawab maka point yang didapatkan adalah 0 . Pengolahan data mentah untuk mendapatkan nilai akhir dimana akumulasi nilai siswa (data mentah) dibagi dengan skor maksimal kemudian dikalikan dengan 100. Berikut disajikan hasil evaluasi proses belajar siswa kelas eksperiment seperti table 01 di bawah ini.

Tabel 01. Hasil Belajar Kelas Eksperimen dan Kelas Kontrol

\begin{tabular}{|c|c|c|c|c|c|c|}
\hline No & $\mathrm{X} 1$ & $\mathrm{X} 2$ & $x 1^{\prime}$ & x2' & $x 1^{\prime 2}$ & $x 2^{\prime 2}$ \\
\hline 1 & 100 & 80 & 9,03 & 14,90 & 81,58 & 222,01 \\
\hline 2 & 100 & 80 & 9,03 & 14,90 & 81,58 & 222,01 \\
\hline 3 & 100 & 80 & 9,03 & 14,90 & 81,58 & 222,01 \\
\hline 4 & 100 & 80 & 9,03 & 14,90 & 81,58 & 222,01 \\
\hline 5 & 100 & 73 & 9,03 & 7,90 & 81,58 & 62,41 \\
\hline 6 & 100 & 73 & 9,03 & 7,90 & 81,58 & 62,41 \\
\hline 7 & 100 & 73 & 9,03 & 7,90 & 81,58 & 62,41 \\
\hline 8 & 100 & 73 & 9,03 & 7,90 & 81,58 & 62,41 \\
\hline 9 & 100 & 73 & 9,03 & 7,90 & 81,58 & 62,41 \\
\hline 10 & 100 & 73 & 9,03 & 7,90 & 81,58 & 62,41 \\
\hline 11 & 100 & 73 & 9,03 & 7,90 & 81,58 & 62,41 \\
\hline 12 & 93 & 73 & 2,03 & 7,90 & 4,13 & 62,41 \\
\hline 13 & 93 & 73 & 2,03 & 7,90 & 4,13 & 62,41 \\
\hline 14 & 93 & 73 & 2,03 & 7,90 & 4,13 & 62,41 \\
\hline 15 & 93 & 73 & 2,03 & 7,90 & 4,13 & 62,41 \\
\hline 16 & 93 & 60 & 2,03 & $-5,10$ & 4,13 & 26,01 \\
\hline 17 & 93 & 60 & 2,03 & $-5,10$ & 4,13 & 26,01 \\
\hline 18 & 86 & 60 & $-4,97$ & $-5,10$ & 24,68 & 26,01 \\
\hline 19 & 86 & 60 & $-4,97$ & $-5,10$ & 24,68 & 26,01 \\
\hline 20 & 86 & 60 & $-4,97$ & $-5,10$ & 24,68 & 26,01 \\
\hline 21 & 86 & 53 & $-4,97$ & $-12,10$ & 24,68 & 146,41 \\
\hline 22 & 86 & 53 & $-4,97$ & $-12,10$ & 24,68 & 146,41 \\
\hline 23 & 86 & 53 & $-4,97$ & $-12,10$ & 24,68 & 146,41 \\
\hline 24 & 86 & 53 & $-4,97$ & $-12,10$ & 24,68 & 146,41 \\
\hline 25 & 80 & 53 & $-10,97$ & $-12,10$ & 120,29 & 146,41 \\
\hline 26 & 80 & 53 & $-10,97$ & $-12,10$ & 120,29 & 146,41 \\
\hline 27 & 80 & 53 & $-10,97$ & $-12,10$ & 120,29 & 146,41 \\
\hline 28 & 80 & 53 & $-10,97$ & $-12,10$ & 120,29 & 146,41 \\
\hline 29 & 80 & 53 & $-10,97$ & $-12,10$ & 120,29 & 146,41 \\
\hline 30 & 80 & 53 & $-10,97$ & $-12,10$ & 120,29 & 146,41 \\
\hline
\end{tabular}


Jurnal Widya Sastra Pendidikan Agama Hindu, Vol 4, No. 1, 2021

ISSN: 2656-7466

\begin{tabular}{cccccc}
31 & 80 & & $-10,97$ & 120,29 & \\
Jumlah & $\mathbf{2 8 2 0}$ & $\mathbf{1 9 5 3}$ & & $\mathbf{1 . 9 3 6 , 9 7}$ & $\mathbf{3 . 1 6 8 , 7 0}$ \\
\hline
\end{tabular}
$M_{X 1=\frac{\sum X 1}{N}}$
$M_{X 2}=\frac{\sum X 2}{N}$
$M_{X 1}=\frac{\sum 2820}{31}$
$M_{X 2=\frac{1953}{30}}$
$M_{X 1=90,97}$
$M_{X 2=65,10}$

Sebelum uji hipotesis sesuai dengan persyaratan analisis data kuantitatif untuk uji eksperimen maka data dari kedua kelompok harus normal dan homogen. Berdasarkan hasil analisis terhadap data tersebut di atas maka ditemukan bahwa data Kelas Eksperimen (XI MM-1) signifikansi yang diperoleh (KolmogorovSmirnova) $0,055>\alpha(0,05)$, hal ini menunjukkan bahwa variabel model pembelajaran Perpaduan konsep Tri Kaya Parisudha dengan Pelatihan Yoga berdistribusi normal. Demikian juga data kelas kontrol dimana signifikansi yang diperoleh dari analisis SPSS 16.0 for windows sebesar (Kolmogorov-Smirnova) $0,059>\alpha(0,05)$ maka data kelas kontrol tentang dengan model pembelajaran Konvensional berdistribusi normal. Sedangkan uji homogenitas kedua variable hasil analisis diperoleh berdasarkan taraf signifikansi $5 \%(0,05)$ dengan $d k$ pembilang berbanding $d k$ penyebut $(n 1-1):(n 2-1)$ atau $(30: 29)$, diperoleh $F$-tabel $\left(F_{t}\right)$ sebesar $(1,85)$ sedangkan $F_{h}$ yang diperoleh dari rumus di atas sebesar $(1,64)$ hal ini menunjukkan $F_{h}(1,64)<F_{t}(1,84)$. Ini berarti varian eksperimen $(X 1)$ dan varian kontrol (X2) homogen. Setelah semua persyaratan untuk hipotesis terpenuhi selanjutnya dilakukan analisis data untuk uji hipotesis. Menggunakan taraf signifikansi $5 \%(0,05)$ dengan uji satu pihak (one tail test) dengan $d k=(n 1+n 2)-2$ atau $\mathrm{dk}=(31+30)-2=59$ maka koefisien $t$-tabel yang diperoleh sebesar $(2,000)$. Sedangkan th yang diperoleh dalam penelitian ini sebesar $(2,095)$. Ini berarti bahwa th $(2,095)>$ tt $(2,000)$ Signifikan. Berdasarkan pada hasil analisis terdapat perbedaan hasil belajar kelas eksperimen dengan kelas control, jadi terkait dengan judul ini berarti ada pengaruh Pembelajaran Perpaduan Konsep Tri Kaya Parisudha dengan Pelatihan Yoga terhadap prestasi belajar pendidikan Agama Hindu dan budi pekerti secara signifikan siswa Kelas XI SMK Negeri 3 Singaraja. Pengaruh pembelajaran tersebut di atas diperkuat dengan capaian prestasi belajar yang mencolok antara kelas eksperimen dengan kelas kontrol yaitu rata-rata 90,97 dengan 65,10. Perbedaan ini secara eksplisit dilihat dari rata-rata capaian kelas eksperiment $(M \times 1=90,97)$ lebih besar dari rata-rata capaian kelas kontrol $(\mathrm{M} \times 2=65,10)$ sedangkan hasil uji hipotesis dengan alfa $(\alpha=0,05)$ ternyata hasilnya signifikan oleh karena itu ada pengaruh terhadap prestasi belajar pendidikan Agama Hindu siswa Kelas XI SMK Negeri 3 Singaraja. Faktor metode yairu Pembelajaran Perpaduan Konsep Tri Kaya Parisudha dengan Pelatihan Yoga merupakan faktor utama penyebab tingginya prestasi belajar siswa. Hal ini jelas karena konsep pembelajaran Tri Kaya Pari Sudha mengandung indikator aktif yaitu: berpikir, berkata atau berbicara dan melakukan atau mengerjakan menjadikan konsep ini menjadi model atau pendekatan pembelajaran ynag sangat dinamis kreatif dan menyenangkan. Dinamis maksudnya model pembelajaran ini dapat diarahkan kemana saja sesuai dengan isi materi secara kontektual. Kreatif maksudnya model ini menuntun siswa untuk menggunakan pikirannya mencipta atau memproyeksikan suatu gejala dari gejala khusus ke hal 
yang bersifat umum. Hal ini memungkinkan mampu mengembangkan daya pikir konstruktivisme terhadap objek yang dipelajarinya. Menyenangkan dimaksudkan adalah siswa belajar dengan perhatian yang fokus, tekun, serius serta tidak menjemukan (Suyatno, 2012). Dalam analisis data peneliti menggunakan taraf kesalahan sebesar alfa 0,5 hal ini berarti keakuratan hasil yang diperoleh sebesar 95\% maka ada faktor lain sebesar 5\% yang belum mampu dirangkul untuk memberi kontribusi terhadap proses belajar siswa. Adapun faktor-faktor lain yang dimaksud meliputi faktor internal yaitu faktor yang berasal dari diri siswa dan psikologi dan faktor eksternal seperti orang tua, keadaan ekonomi maupun sekolah sesuai dengan teori (Inas Sausan, 2016). Hasil wawancara dengan siswa menunjukkan bahwa model pembelajaran yang digunakan mampu menumbuhkan proses pembelajaran yang aktif, dinamis dengan suasana menyenangkan. Fenomena ini sejalan dengan pandangan para peneliti sebelumnya yang menyatakan bahwa metode yang memiliki sifat eksplorasi, trial and errol yang berbasis logika deduktif ataun induktif mampu meningkatkan proses dan hasil belajar. Metode pembelajaran guru adalah komponen yang sangat menentukan dalam implementasi suatu strategi pembelajaran. Berdasarkan pendapat ini dapat ditegaskan bahwa salah satu faktor eksternal yang sangat berperan mempengaruhi prestasi belajar siswa adalah guru. Guru dalam proses pembelajaran memegang peranan yang sangat penting. Peran guru, apalagi untuk siswa pada usia sekolah dasar, tak mungkin dapat di gantikan oleh perangkat lain seperti televisi, radio dan komputer. Sebab siswa adalah organisme yang sedang berkembang yang memerlukan bimbingan dan bantuan orang dewasa. Prestasi belajar siswa merupakan prestasi dari suatu proses yang di dalamnya terlibat sejumlah faktor yang saling mempengaruhinya. Perpaduan Konsep Tri Kaya Parisudha dengan Pelatihan Yoga, suatu pembelajaran yang kontruktivistik yang mempunyai ciri-ciri penggunaan masalah nyata sebagai konteks siswa yang mempelajari cara berpikir kritis serta keterampilan dalam memecahkan masalah, sehingga ini merupakan metode yang baik digunakan sebagai metode pembelajaran untuk mengaktifkan siswa dalam proses pembelajaran (Fitri, 2017). Metode ini juga digunakan baik dalam pembelajaran individual ataupun pembelajaran berkelompok sehingga hasil yang didapatkan adalah pembelajaran yang bermakna. Selain Metode ini sebagai metode utama metode pendukung dalam penelitian ini adalah menggunakan konsep Tri kaya Parisudha dengan pelatihan Yoga yang merupakan konsep adi luhung pada agama Hindu. Penggunaan konsep ini berperan penting dalam pengaktifan serta menunjang prestasi siswa dalam proses pembelajaran kaitannya terhadap ranah ketuntasan belajar yakni ranah kongnitif, afektif dan psikomotor. Jadi berdasarkan hasil analisis yang dilakukan terhadap proses pembelajaran meningkatnya perhatian siswa terhadap proses pembelajaran serta meningkatnya Prestasi belajar (kognitif) siswa disebabkan karena pengaruh pembelajaran perpaduan konsep Tri Kaya Parisudha dengan pelatihan Yoga secara benar, baik dan tepat, dapat mengoptimalkan proses pembelajaran terutama pada aspek kongnitif siswa, sehingga proses belajar mengajar menjadi aktif, kreatif, efektif dan menyenangkan. Dengan demikian, guru hendaknya dapat mengaplikasikan pembelajaran perpaduan konsep Tri Kaya Parisudha dengan pelatihan Yoga ini salah satu pembelajaran dalam upaya peningkatan prestasi belajar siswa (Sentana, 2017)

\section{PENUTUP}


Jurnal Widya Sastra Pendidikan Agama Hindu, Vol 4, No. 1, 2021

ISSN: 2656-7466

Berdasar hasil analisis disimpulkan bahwa peningkatan proses dan prestasi belajar siswa ditentukan oleh model pembelajaran yang digunakan oleh guru. Penelitian ini telah menemukan sebuah model pembelajaran yang diambil dari konsep ajaran Agama Hindu yaitu Perpaduan Konsep Tri Kaya Parisudha dengan Pelatihan Yoga. Ada tiga indikator pembelajaran dalam konsep Tri Kaya Parisudha yang menjadi fokus pengembangan kegiatan yang terintegrasi yaitu; berpikir, berkata/berbicara dan berbuat atau mengerjakan. Pembelajaran berpikir artinya guru diberi hak seluas-luasnya mengembangkan materi ajar yang berorientasi pada mengaktifkan mental atau berpikir. Berbicara artinya guru diberi hak seluas-luasnya untuk mengembangkan materi ajar yang berbasis pada aspek berbicara. Sedangkang melakukan atau mengerjakan guru diberi kesempatan dalam mengembangkan materi ajar yang berorientasi pada aktivitas fisik seperti: menulis (membuat laporan), mengerjakan, menemukan, menganalisis dan sejenisnya. Rekomendasi penelitian ini ditujukan kepada analist, Resarcher terutama guru agar lebih banyak menggali atau membuat penelitian eksperimen khusus dibidang metode pembelajaran dengan mengambil aspek atau indikator yang terkandung dalm konsep ajaran Agama Hindu. Mampu menggunakan metode tersebut di atas dalam pembelajaran dengan tepat dan benar.

\section{DAFTAR PUSTAKA}

Fitri, R. (2017). PENGEMBANGAN PERANGKAT PEMBELAJARAN BERBASIS PENDEKATAN KONSTRUKTIVISME UNTUK MENINGKATKAN KEMAMPUAN PEMAHAMAN KONSEP PADA MATERI PERSAMAAN LINGKARAN. Jurnal Nasional Pendidikan Matemtika, 1.

Inas Sausan, dkk. (2016). FAKTOR-FAKTOR INTERNAL YANG BERPENGARUH TERHADAP PRESTASI

BELAJAR SISWA PADA POKOK BAHASAN KONSEP MOL. Paedagogia Jurnal

Penelitian Pendidikan, 19

Nabila Yuliana. (2018). PENGGUNAAN MODEL PEMBELAJARAN DISCOVERY

LEARNING DALAM

PENINGKATAN HASIL BELAJAR SISWA DI SEKOLAH DASAR. Jurnal IImiah Pendidikan dan

Pembelajaran, 2

Prihma Sinta Utami,dkk. (2015). PENGARUH METODE PEMBELAJARAN DAN GAYA BELAJAR SISWA TERHADAP HASIL BELAJAR IPS DI SMP NEGERI

DI KOTA YOGYAKARTA. Harmoni Sosial Jurnal Pendidikan IPS, 2

Rusli, A. R. (2017). SPIRITUALITAS DALAM AGAMA HINDU. Majalah IImu

Pengetahuan Dan Pemikiran Keagamaan Tajdid, 20.

Sentana, G. D. D. (2017). PENANAMAN KONSEP TRI KAYA PARISUDHA DALAM TRADISI MARERAOSAN. Guna Widya: Jurnal Pendidikan Hindu, 4.

Suanthara, I. N. D. E. (2020). Strategi Penerapan Tri Hita Karana Pada SMP Negeri 
Jurnal Widya Sastra Pendidikan Agama Hindu, Vol 4, No. 1, 2021

ISSN: 2656-7466

5 Singaraja. Jurnal Widya Sastra Pendidikan Agama Hindu, 3(2), 50-63.

SUGIYONO. (2003). METODE PENELITIAN ADMINISTRASI (10th ed.). CV ALPFABETA.

Suyatno. (2012). PENGGUNAAN METODE PEMBELAJARAN YANG

MENYENANGKAN DAN BERMOTIVASI. Dieksis,4

Suradarma, I. B. (2019). PENDIDIKAN AGAMA HINDU SEBAGAI LANDASAN

PENDIDIKAN MORAL DAN ETIKA. Jurnal IImiah Dinamika Sosial, 3. 